\title{
Sub-acute Toxicity of Aqueous Extracts of Tephrosia vogelii, Vernonia amygdalina and Senna occidentalis in Rats Immaculate Nabukenya ${ }^{1 *}$, Chris Rubaire-Akiiki ${ }^{1}$, Denis Mugizi' ${ }^{1}$, John Kateregga' ${ }^{1}$, Deogracious Olila1 and Johan Höglund ${ }^{2}$
}

${ }^{1}$ College of Veterinary Medicine, Animal Resources and Biosecurity, Makerere University, P.O. Box 7062, Kampala, Uganda

${ }^{2}$ Department of Biomedical Sciences and Veterinary Public Health, Section for Parasitology, Swedish University of Agricultural Sciences, P.O. Box 7063, Uppsala, Sweden

\begin{abstract}
There is an intense search for new plant-derived medicines to match the ever increasing prevalence of drug resistance. Toxicity profiles of three commonly used plants against helminthosis in Uganda will support their optimum use.

Objective: To evaluate the sub-acute toxicity of aqueous leaf extracts of Tephrosia vogelii (TV), Vernonia amygdalina (VA) and Senna occidentalis (SO).

Methods: One hundred Wistar white albino rats in 10 groups were dosed orally daily with 200,400 and $600 \mathrm{mg} / \mathrm{kg}$ of TV, VA and SO for 28 days or Goodwin's physiological solution. Daily changes in behaviour, feed/water intake and weight (weekly) were monitored. On day 29, blood for haematology, serum for biochemical analysis and organs (lungs, liver, kidney, heart and small intestines) for histopathology were collected.

Results: Continued exposure of rats to $600 \mathrm{mg} / \mathrm{kg}$ doses of SO and VA extracts led to elevation of ALT, AST and ALP and cholesterol in the treatment groups. SO and VA at $600 \mathrm{mg} / \mathrm{kg}$ elevated urea and uric acid; depressed bilirubin while VA and TV $600 \mathrm{mg} / \mathrm{kg}$ caused the reverse. Histopathology findings (villi sloughing, pneumonitis, liver and kidney degeneration) further supported these results.
\end{abstract}

Conclusion: The very low toxicity of the aqueous leaf extracts of TV, VA and SO at high doses makes them safe at currently non-standardised doses used for animal treatment.

Keywords: Tephrosia vogelii; Vernonia amygdalina; Senna occidentalis; Toxicity; Rats

\section{Background}

Uganda has $80 \%$ of its population depending on agriculture and about $50 \%$ are engaged in livestock farming [1]. In small-scale livestock production, majority of the farmers use a combination of conventional and ethnopharmacological formulations to treat diseases and parasite infections [2,3]. Use of plants in animal disease treatment is practiced traditionally [2,4-6], albeit with non-standardised doses as a major shortfall $[4,7,8]$. This is further compounded by the basic belief that plant extracts are non-toxic [2,7,9]. In an earlier study mapping ethnopharmacological practices in Mpigi and Gulu districts in Uganda, farmers prioritized Vernonia amygdalina (VA), Tephrosia vogelii (TV) and Senna occidentalis (SO) for detailed evaluation [3].

Tephrosia vogelii Hook (Family Leguminosae; synonym Cracca vogelii, Hook F; ILDIS record 5085), is a soft woody branching herb, 1-4 $\mathrm{m}$ tall [10]. The plant is widely promoted in eastern and southern Africa for its insecticidal properties [11], although some people use it as a fish poison [12]. Vernonia amygdalina Delile (Family Asteraceae; synonym Cacalia amygdalina (http://www.theplantlist.org/tpl/record/ gcc-84295) Kuntze, TICA Id 2949) is a shrub that grows predominantly in tropical Africa $[2,10]$. The leaf extracts of VA are used to treat malaria, gastrointestinal ailments [13-16] and reducing blood sugar levels in dogs [17]. Senna occidentalis Linn (Family Caesalpiniaceae; synonym Cassia occidentalis L.; ILDIS id 1087), is a $0.8-1.5 \mathrm{~m}$ tall, smooth leafed perennial plant important in traditional medicine in the tropics $[10,18]$. It has good antimicrobial, anti-mutagenic, anti-inflammatory, anti-diabetic and anti-malarial activity [18-20]. Acute toxicity studies of leaves of TV [21], VA $[15,22,23]$ and seeds of SO [24-28] have been studied in different animals. The objective of this study was to determine the sub-acute toxicity due to prolonged administration of these three commonly used plants in rats.

\section{Materials and Methods}

\section{Plant collection and extract preparation}

Fresh leaves of all plants were collected in January 2013 from wild shrubs at Mbarara Zonal Agricultural Research Development Institute farm, located $274 \mathrm{~km}$ south-west of Kampala, the capital of Uganda. The voucher specimens were confirmed by a botanist and deposited in Makerere University Herbarium (numbers SO - NI 02, VA - NI 03 and TV - NI 04). The leaves were dried under shade in the laboratory for two weeks. They were ground to fine powder with an automated electric grinder (Grindomix, Retsch, GM 200). For aqueous extraction, $500 \mathrm{~g}$ of powder from each plant was infused in 21 of hot distilled water for 24 hours with regular stirring (metallic magnet). After filtration with a $4 \mathrm{~mm}$ Whatmann filter paper, the filtrate was freeze dried at $-82^{\circ} \mathrm{C}$. The dried extracts were weighed and stored at $4^{\circ} \mathrm{C}$ until needed.

\section{Animal dosing and monitoring}

After determining the lethal doses and safety margins of the aqueous extracts, the safest dose was used to calculate doses for the sub-

*Corresponding author: Immaculate Nabukenya, Department of Biosecurity Ecosystems and Veterinary Public Health, Uganda, Tel: +256-754600895; E-mail: Pollen.Yeung@Dal.Ca

Received June 25, 2014; Accepted July 22, 2014; Published July 24, 2014

Citation: Nabukenya I, Rubaire-Akiiki C, Mugizi D, Kateregga J, Olila D, et al (2014) Sub-acute Toxicity of Aqueous Extracts of Tephrosia vogelii, Vernonia amygdalina and Senna occidentalis in Rats. Nat Prod Chem Res 2: 143. doi:10.4172/2329-6836.1000143

Copyright: (c) 2014 Nabukenya I, et al. This is an open-access article distributed under the terms of the Creative Commons Attribution License, which permits unrestricted use, distribution, and reproduction in any medium, provided the original author and source are credited. 
acute study. In the protocol, OECD test guidelines were followed [29]. National Academies guide for the care and use of laboratory animals [30] were adapted for the animal protocol in this study and was approved by the institutional review board (study number IRBCOVAB/2013/009). Briefly, 100 Wistar white albino rats ( 50 females and 50 males), of about 6 to 8 weeks old weighing 70-100 g were procured from Uganda Virus Research Institute and kept for two weeks to acclimatize to the new laboratory conditions. Each extract was reconstituted in Goodwin's physiological solution to a stock concentration of $200 \mathrm{mg} / \mathrm{ml}$. The rats were weighed and randomly assigned to 10 treatment groups i.e. of each extract, $200 \mathrm{mg} / \mathrm{kg}, 400 \mathrm{mg} / \mathrm{kg}$ and $600 \mathrm{mg} / \mathrm{kg}$ body weight plus the negative control (given Goodwin's physiological solution w/v). In each group, the number of females and males was equal. Each group was kept in $80 \times 50 \mathrm{~cm}$ wooden cages, fed on commercial rodent feed (Unga Limited, Kenya) and given water ad libitum. The rats were treated once daily, while body weights were taken once a week and on the $29^{\text {th }}$ day, before termination of the experiment.

\section{Sample collection}

On the $29^{\text {th }}$ day, the rats were weighed, anaesthetised with $70 \%$ chloroform (trichloromethane, E08A/0808/2104/13, Fine-Chem, India) for ten minutes before blood and tissue collection. Whole blood collected by cardiac puncture was transferred into labelled plain and EDTA vaccutainer tubes (BD Plymouth, UK). EDTA blood was kept at $4^{\circ} \mathrm{C}$ while non-EDTA blood was centrifuged at $1500 \mathrm{~g}$ for three minutes to separate serum, which was kept at $-20^{\circ} \mathrm{C}$. The rats were then dissected to collect the liver, kidneys, small intestine sections, heart and lungs; which were weighed and kept in $10 \%$ buffered formalin for histopathology.

\section{Haematological and biochemical tests}

The EDTA whole blood for haematology was processed within 24 hours as described previously [31]. The automated haematological analyser (Coulter STKS, Beckman) was used to obtain the following; white blood cell counts (WBC), differential counts of neutrophils, lymphocytes, monocytes, oesinophils and basophils; red blood cells (RBC), haemoglobin (Hb), haematocrit (HCT), mean corpuscular volume (MCV), mean corpuscular haemoglobin concentration (MCHC), mean corpuscular haemoglobin $(\mathrm{MCH})$, red blood cell width to corpuscular volume (RDW-CV), mean platelet volume (MPV) and platelets (PLT). Serum kept at $-20^{\circ} \mathrm{C}$ was thawed to $25^{\circ} \mathrm{C}$ and processed within two days after collection in the clinical chemistry laboratory at Mulago Hospital. Biochemical analysis using an automated analyser (Medonic, CA620, Boule, Sweden) was conducted for blood urea nitrogen (BUN), creatinine, Aspartate aminotransferase (AST), alanine aminotransferase (ALT), uric acid (UA), total cholesterol, triglycerides, alkaline phosphatase (ALP), total protein (TP), albumin, total and direct bilirubin. The control group mean values were used as the baseline for comparison with treatment groups.

\section{Histopathology}

Whole rat organs kept in $10 \%$ buffered formalin for two weeks were processed in the Central Diagnostic Laboratory of the College of Veterinary Medicine at Makerere University. Sections of the liver, kidney, lung, small intestines and heart were prepared as described previously [31,32]. Sections were stained with Haemotoxylin and Eosin $(\mathrm{H} \& \mathrm{E})$, and then microscopically examined for pathological changes at $\mathrm{x} 10,20$ and 40 magnifications.

\section{Data analysis}

Laboratory data was entered in Microsoft Excel and analysed in Minitab 16.0 (Minitab Inc., USA). Means, standard deviation, standard error of the mean, median and 95\% confidence intervals of ontinuous variables were calculated and plotted by a pre-designed Excel sheet [33]. One-way analysis of variance (ANOVA) and Tukey's high square difference test were used to compare mean differences for different parameters in the treatment and control groups. Proportions and percentages were computed and compared across groups using the Mann-Whitney, Newman-Keuls and Chi-square tests. The level of significance was set at $\mathrm{P}<0.05$.

\section{Results}

\section{Physical signs and gross necropsy findings}

In all treatment groups, we observed no changes in feed and water intake. There were three deaths (one each at $600 \mathrm{mg} / \mathrm{kg}$ of TV, SO and VA) after 15, 24 and 26 days after treatment respectively. The immediate cause was wounds due to cannibalism, but after housing the rats individually, no more deaths were registered. No pathological gross necropsy findings were detected in treated and control rats during organ collection and processing.

\section{Effect on body, heart, liver and kidney weights}

There was a gradual increase in body weight in rats across all treatment groups but mean weight of SO $600 \mathrm{mg} / \mathrm{kg}$ was lower than other groups at day 0 and 14 . However, the difference was non-existent by day 21 and at the end of experiment (day 29). There was less variation of mean post-mortem weight of the kidney and liver in the treatment groups. Although the liver weights ranged from 4.6-9.7 g, there was no statistical difference in mean weights due to treatment.

\begin{tabular}{|c|c|c|c|c|c|c|c|c|c|c|}
\hline $\begin{array}{l}\text { Treat group \& } \\
\text { dose (mg/kg) }\end{array}$ & WBC $\left(10^{3} / \mu \mathrm{l}\right)$ & RBC $\left(10^{6} / \mu \mathrm{l}\right)$ & HGB (g/dL) & НСТ (\%) & MCV (fL) & $\mathrm{MCH}(\mathrm{pg})$ & MCHC (g/dL) & RDWCV (\%) & PLT $\left(10^{3} / \mu \mathrm{l}\right)$ & MPV (fL) \\
\hline SO 200 & $13.1 \pm 2.2$ & $7.6 \pm 0.2$ & $13.4 \pm 0.2$ & $46.5 \pm 1.2$ & $61.3 \pm 1.2$ & $17.7 \pm 0.3$ & $28.9 \pm 0.3$ & $23.0 \pm 0.8$ & $869.7 \pm 52.7$ & $8.9 \pm 0.2$ \\
\hline SO 400 & $13.3 \pm 3.1$ & $7.1 \pm 0.4$ & $12.9 \pm 0.7$ & $45.5 \pm 3.1$ & $63.7 \pm 1.6$ & $18.1 \pm 0.3$ & $28.5 \pm 0.5$ & $23.2 \pm 1.4$ & $832.5 \pm 106.8$ & $8.6 \pm 0.2$ \\
\hline SO 600 & $9.5 \pm 2.6$ & $6.7 \pm 0.2$ & $12.7 \pm 0.5$ & $41.5 \pm 2.1$ & $62.2 \pm 1.5$ & $19.1 \pm 0.3$ & $30.7 \pm 0.4$ & $26.2 \pm 4.6$ & $684.7 \pm 16.0$ & $8.8 \pm 0.1$ \\
\hline Control & $19.6 \pm 10.5$ & $7.4 \pm 0.3$ & $13.5 \pm 0.4$ & $44.9 \pm 2.3$ & $60.7 \pm 2.3$ & $18.4 \pm 0.4$ & $30.4 \pm 0.8$ & $19.5 \pm 0.6$ & $733.8 \pm 34.8$ & $8.6 \pm 0.3$ \\
\hline TV200 & $9.3 \pm 1.6$ & $7.5 \pm 0.5$ & $13.2 \pm 0.7$ & $46.7 \pm 3.2$ & $62.5 \pm 1.2$ & $17.7 \pm 0.2$ & $28.5 \pm 0.6$ & $21.6 \pm 1.0$ & $731.8 \pm 34.4$ & $9.2 \pm 0.6$ \\
\hline TV400 & $9.9 \pm 2.4$ & $7.0 \pm 0.5$ & $12.7 \pm 0.7$ & $42.2 \pm 2.3$ & $60.7 \pm 1.1$ & $18.3 \pm 0.4$ & $30.2 \pm 0.2$ & $23.1 \pm 1.1$ & $362.5 \pm 95.3^{a}$ & $9.6 \pm 0.2$ \\
\hline TV600 & $14.6 \pm 4.3$ & $5.9 \pm 1.1$ & $11.4 \pm 1.4$ & $39.3 \pm 6.1$ & $67.1 \pm 2.4$ & $19.7 \pm 1.2$ & $29.3 \pm 0.9$ & $22.7 \pm 2.4$ & $397.7 \pm 78.9^{a}$ & $8.5 \pm 0.0$ \\
\hline VA200 & $10.5 \pm 0.7$ & $7.3 \pm 0.5$ & $13.0 \pm 0.9$ & $46.0 \pm 3.6$ & $63.1 \pm 1.1$ & $17.8 \pm 0.2$ & $28.3 \pm 0.7$ & $22.9 \pm 0.7$ & $849.0 \pm 87.6$ & $8.7 \pm 0.2$ \\
\hline VA400 & $11.4 \pm 0.5$ & $7.7 \pm 0.9$ & $14.3 \pm 0.8$ & $49.6 \pm 5.6$ & $64.4 \pm 1.4$ & $18.5 \pm 0.3$ & $28.8 \pm 0.3$ & $21.1 \pm 1.0$ & $943.0 \pm 56.3$ & $9.1 \pm 0.1$ \\
\hline VA600 & $13.1 \pm 2.9$ & $8.1 \pm 0.3$ & $14.5 \pm 0.1$ & $50.9 \pm 1.2$ & $63.2 \pm 1.1$ & $18.0 \pm 0.6$ & $28.5 \pm 0.4$ & $21.3 \pm 0.8$ & $714.0 \pm 109.0$ & $9.7 \pm 0.3$ \\
\hline
\end{tabular}

aMean Platelet values significantly different from control and other treatment groups; $P=0.005$

Table 1: Haematological parameters (Mean \pm SEM) of 100 Wistar white albino rats in nine treatment groups and a placebo control group. 
Citation: Nabukenya I, Rubaire-Akiiki C, Mugizi D, Kateregga J, Olila D, et al. (2014) Sub-acute Toxicity of Aqueous Extracts of Tephrosia vogelii, Vernonia amygdalina and Senna occidentalis in Rats. Nat Prod Chem Res 2: 143. doi:10.4172/2329-6836.1000143

Page 3 of 5

\section{Effect on biochemical and haematological parameters}

The extracts caused varied effects on haematology and biochemistry (Table 1). For example, there was depression of haematocrit in a doseresponse pattern, whereas the $\mathrm{WBC}$ counts were much higher in the control $\left(19.6 \pm 10.5 \times 10^{3} / \mu \mathrm{l}\right)$ compared to other groups $\left(<15 \times 10^{3} / \mu \mathrm{l}\right)$. A reverse relationship was observed with RDCHV; showing elevated levels with increasing doses for all plant extracts but there was minimal change in MCHC. At increasing doses, TV had a significant reducing effect on the mean platelet counts compared to other treatment groups and the controls $\left(\mathrm{F}_{9,89}=3.4 ; \mathrm{P}=0.005\right)$.

Levels of liver function enzymes; ALP, ALT, AST and cholesterol significantly differed across the treatment groups $\left(\mathrm{F}_{9,89}=2.88, \mathrm{P}=0.035\right.$; $2.55,0.022 ; 2.32,0.035$ and 3.35, 0.004 respectively). At $600 \mathrm{mg} / \mathrm{kg}$, TV elevated the AST enzyme to $355.6 \mathrm{U} / \mathrm{L}$ while SO $600 \mathrm{mg} / \mathrm{kg}$ depressed it to $182.0 \mathrm{U} / \mathrm{L}$, compared to $227.1 \mathrm{U} / \mathrm{L}$ in the control group (Figure 1). Cholesterol levels also differed in SO $600 \mathrm{mg} / \mathrm{kg}$ (3.55), VA $600 \mathrm{mg} / \mathrm{kg}$ (3.38) and TV $200 \mathrm{mg} / \mathrm{kg}$ (2.13), TV $600 \mathrm{mg} / \mathrm{kg}$ (2.36) compared to 2.93 in the control group (Figure 1A and 1B). Furthermore, albumin protein was elevated in SO and VA in dose-response manner compared to TV, which led to a small change (Table 2). The elevation was significant at $600 \mathrm{mg} / \mathrm{kg}$ of SO $(44.9 \mathrm{~g} / \mathrm{L})$ and VA $(47.8 \mathrm{~g} / \mathrm{L})$ compared to TV $(38.2$ $\mathrm{g} / \mathrm{L})$ and control group $(34.8 \mathrm{~g} / \mathrm{L})$.

\section{Histopathology and microscopic effects of the treatments}

As shown in Table 3 and Figure 2A-2F, there were varied effects of treatments on the histopathology of the liver, kidney, lung, heart and small intestines. TV caused more toxic changes in the organs

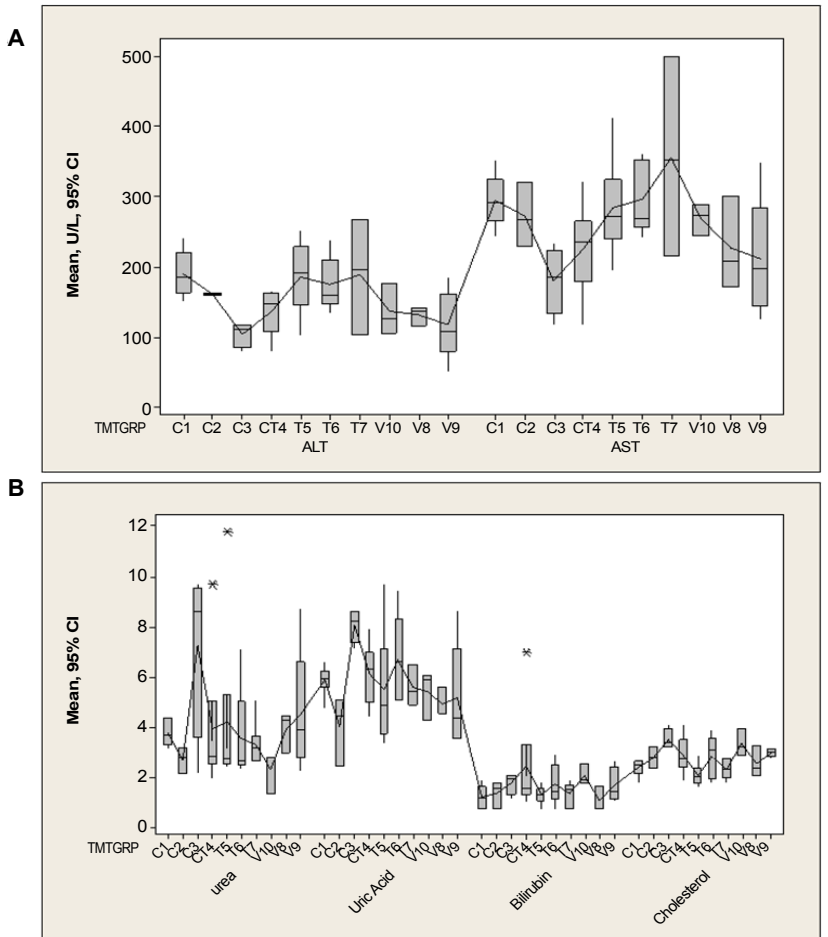

Figure 1:A: Comparison of mean (U/L) and $95 \% \mathrm{Cl}$ of liver function enzymes - Alanine amino-transferase (ALT) and Aspartate amino-transferase (AST) in 9 treatment groups with non-treated (control) rats. B: Mean and $95 \% \mathrm{Cl}$ of urea, uric acid, bilirubin and cholesterol in 100 rats.

\begin{tabular}{|c|c|c|c|c|}
\hline $\begin{array}{l}\text { Treatment } \\
\text { Group (mg/kg) }\end{array}$ & Mean (g/L) & Std. Error & \multicolumn{3}{|c|}{ 95\% Confidence Interval for Mean } \\
\hline & & & Lower Bound & Upper Bound \\
\hline SO 200 & $35.5^{\mathrm{a}, \mathrm{b}}$ & 2.6 & 28.8 & 42.2 \\
\hline SO 400 & 39.3 & 3.7 & 23.6 & 55.0 \\
\hline SO 600 & $44.9^{\mathrm{a}, \mathrm{c}}$ & 0.9 & 41.9 & 47.8 \\
\hline Control & $34.3^{\mathrm{b}, \mathrm{c}}$ & 6.0 & 18.8 & 49.7 \\
\hline TV 200 & 35.5 & 1.1 & 32.8 & 38.3 \\
\hline TV 400 & 35.4 & 2.4 & 29.3 & 41.6 \\
\hline TV 600 & 38.2 & 2.5 & 31.1 & 45.2 \\
\hline VA 200 & $38.3^{\mathrm{b}}$ & 5.7 & 13.7 & 62.9 \\
\hline VA 400 & $41.7^{\mathrm{b}}$ & 2.5 & 34.8 & 48.6 \\
\hline VA 600 & $47.8^{\mathrm{b}}$ & 2.4 & 37.6 & 58.1 \\
\hline
\end{tabular}

*Control rats given $0.5 \mathrm{ml}$ of Goodwin's physiological solution daily aMean significantly different at $\mathrm{P}<0.05$

bMean different between VA 600 and all groups with letter $\mathrm{b}$

Table 2: Mean and $95 \% \mathrm{Cl}$ of albumin ( $\mathrm{g} / \mathrm{L}$ ) protein levels in blood of 100 rats in nine treatment groups compared to placebo control group.

compared to SO and VA. For example, at TV $600 \mathrm{mg} / \mathrm{kg}$, villi sloughing in intestines, myocardial and renal congestion as well as hyaline degeneration of the liver were recorded. Slight pneumonitis in the lungs with mononuclear cell infiltration was also noted in TV $600 \mathrm{mg} /$ $\mathrm{kg}$ (Figure 2). Most of the changes followed a dose-response pattern.

\section{Discussion}

The geographical location, season, soil type, climate differences, agronomic practices, plant part and age affect the concentration of phytochemicals, usually leading to differences in bioactivity and toxicity $[7,16,18]$. Using proteomics, metabolomics and transcriptomics in recent advances to determine nephrotoxic, genotoxic and teratogenic effects of natural plant products has been recommended [34]. These in silico, in vitro and in vivo methods which may explain the mechanisms of action, are however still unstandardised [34]. Following the established protocol $[29,33]$, the recommended number of animals used supported statistical analysis.

The difference in concentration of phytochemicals extracted by various solvent systems may account for differences in observed toxicity of a plant extract at the same doses. For example, saponins are incriminated to cause haemolysis [35]. Although VA has significant levels of saponins [36,37], there was a dose-dependent increase in RBC counts. On the contrary, a reduction in RCB counts with increasing doses of SO and TV and PCV was noted. This is a possible mechanism of toxicity for the latter two extracts. Although no specific study on effect of extract on platelet count was done, we observed a marked reduction in platelets in higher dose groups of TV (363 and 398 compared to $734 \times 10^{3} / \mu \mathrm{l}$ in control). When platelets are significantly reduced, there may be multiple organ failure, eventually leading to toxicity signs or death.

Specifically, rotenone present in TV $[11,38]$, causes similar signs of poisoning in humans and is one of the possible chemicals responsible for the observed acute toxicity [21]. In insects and fish, rotenone interferes with mitochondrial electron transport system, whereas mammals are more tolerant [38]. Rotenone however, is less soluble in water and easily disintegrates in the environment [12] which explains the presently observed reduced toxicity by aqueous extracts. Anthracenosides and anthocyanosides have been incriminated as toxic phytochemicals previously. However, qualitative phytochemistry (results not presented here) showed both anthracenosides and anthocyanosides in the aqueous extract of TV and VA. 
Citation: Nabukenya I, Rubaire-Akiiki C, Mugizi D, Kateregga J, Olila D, et al. (2014) Sub-acute Toxicity of Aqueous Extracts of Tephrosia vogelii, Vernonia amygdalina and Senna occidentalis in Rats. Nat Prod Chem Res 2: 143. doi:10.4172/2329-6836.1000143

Page 4 of 5

\begin{tabular}{|c|c|c|c|c|c|c|c|c|c|}
\hline \multirow[t]{2}{*}{ Body organ } & \multicolumn{9}{|c|}{ Treatment dose $\mathrm{mg} / \mathrm{kg}$ body weight } \\
\hline & TV 200 & TV 400 & TV 600 & VA 200 & VA 400 & VA 600 & SO 200 & SO 400 & So 600 \\
\hline Liver & $\mathrm{NL}$ & & DG & & $\mathrm{NL}$ & $\mathrm{NL}$ & $\mathrm{NL}$ & $\mathrm{NL}$ & $\mathrm{NL}$ \\
\hline Kidney & & & CG & CG,HD & $\mathrm{NL}$ & CG & $\mathrm{NL}$ & $\mathrm{NL}$ & $\mathrm{NL}$ \\
\hline Small intestines & $\mathrm{NL}$ & & & & $\mathrm{NL}$ & $\mathrm{NL}$ & VS & $\mathrm{NL}$ & $\mathrm{NL}$ \\
\hline Lung & CG; PN & & LE, PN, MN & & NL & & $\mathrm{NL}$ & $\mathrm{NL}$ & $\mathrm{NL}$ \\
\hline Heart & $\mathrm{NL}$ & $\mathrm{NL}$ & $\mathrm{NL}$ & $\mathrm{NL}$ & $\mathrm{NL}$ & $\mathrm{NL}$ & NL & CG & $\mathrm{NL}$ \\
\hline
\end{tabular}

TV-Tephrosia vogelii VA-Vernonia amygdalina SO-Senna occidentalis NL-No significant lesion VS-Villi sloughing CG-Congestion DG-Degeneration MN-Mononuclear cell infiltration LE-lung oedema Focal areas of hepatic degeneration (pykinosis) were identified in TV 600 dose

Table 3: Histopathology findings in the liver, kidney, lung, heart and small intestines of 40 rats after 28 days daily oral treatment at 200,400 and 600 mg/kg of the three plant extracts.
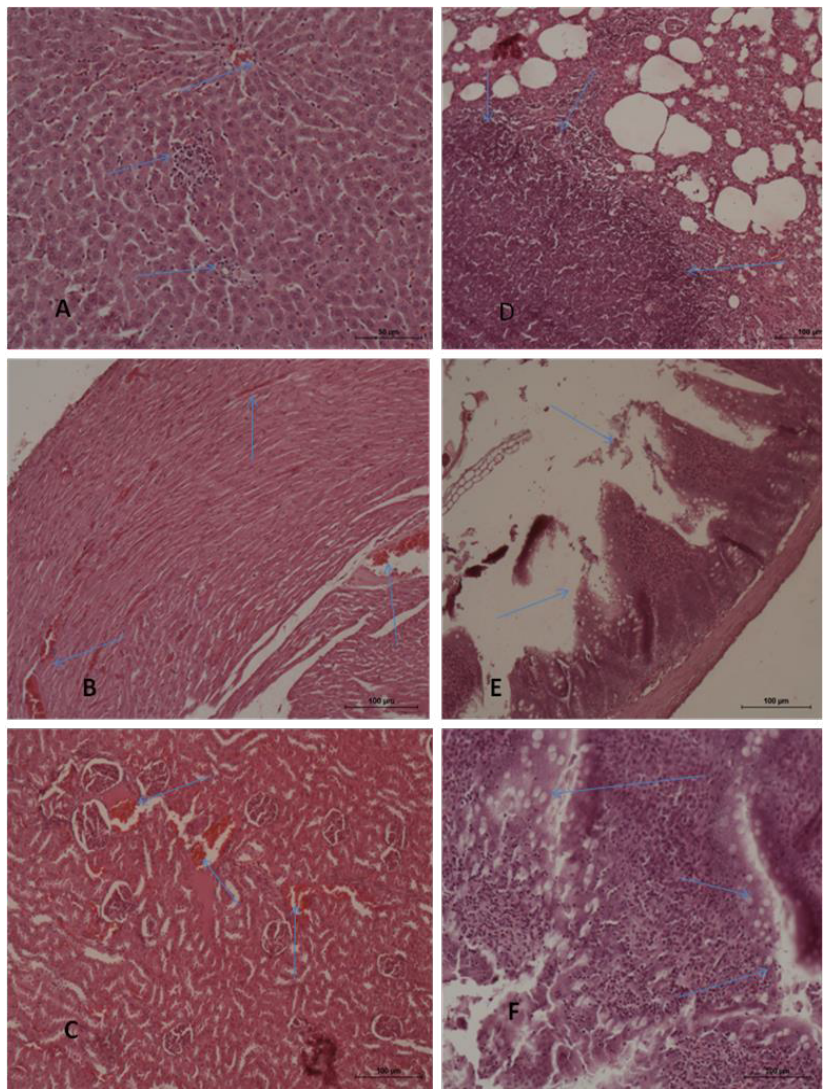

Figure 2: Sub-acute toxic effects of treatments A: Tephrosia vogelii 600 $\mathrm{mg} / \mathrm{Kg}$; Liver-focal areas of hepatic degeneration/pyknosis (Magx20) and B: Kidney - Renal congestion (x10) C: Vernonia amygdalina $600 \mathrm{mg} /$ kg Heart-congestion (x20) D: Lung peribronchular lymphoid necrosis E: Tephrosia vogelii $400 \mathrm{mg} / \mathrm{Kg}$ Small intestines - Villi sloughing (x20) F: Senna occidentalis $600 \mathrm{mg} / \mathrm{Kg}$ Intestine-villi sloughing with intense mononuclear cell infiltration and hyperplasia of goblet cells $(x 40)$

The seeds of SO are reportedly toxic to many vertebrates and the unnamed toxic albumin is incriminated [18]. This study however, considered only the leaf extracts and thus some of these toxic rinciples may have been in limited amounts (no specific tests done presently). Some of the phytochemicals in SO are reported to be hepatoprotective $[18,39]$. In the current study, the $600 \mathrm{mg} / \mathrm{kg}$ dose of aqueous extracts of SO exerted significant decrease in AST, ALT enzymes but increased urea and uric acid compared to the controls and other treatment groups. These results support previous findings that the SO leaf extract is hepatoprotective [39]. On the contrary, in a previous study, there was no change in liver enzymes and haematological parameters in female and male rats for SO at doses as high as $2500 \mathrm{mg} / \mathrm{kg} /$ day [28]. Their study therefore, did not report any toxicity of SO in the male or female rats. SO and VA caused similar biochemical changes in the rats. For example, they both caused depression of ALT and AST in a doseresponse manner; quite the opposite to the effect of TV (elevation with higher doses). In addition, they both caused an elevation in albumin protein. Depression of this protein clearly indicates chronic liver damage compared to elevation of ALT and AST (sometimes caused by muscle damage), thus a better indicator of liver function. This further confirms the hepatoprotective effect of SO and VA as previously discussed $[13,23,39]$.

Although there were no visible gross changes observed in the sampled organs, histopathology results indicated more toxic effects by TV compared to SO and VA. Sloughing of the intestinal villi observed in SO and TV due to continued necrosis can lead to reduced nutrient absorption, which will eventually impair liver and kidney function. Antioxidant activity of SO by reducing DNA degeneration (iron IIdriven Fenton reaction) has been demonstrated with seed extracts. Inhibition of DNA damage by strong ion chelation activity is also hepatoprotective $[18,40]$. In chicken, studies demonstrated lower phosphorylation ratios and respiratory control ratios and oxygen use in liver mitochondria [18]. Pneumonitis, mononuclear cell infiltration and lymphoid necrosis as observed in some cases in this study lead to compromised gaseous exchange and eventual death. Underlying toxicity mechanisms at cellular level should be undertaken with standardised proteomics, metabolomics and transcriptomics.

\section{Conclusion}

SO and VA were hepatoprotective while TV was slightly hepatotoxic in a dose response manner. The very low toxicity of the aqueous leaf extracts of TV, VA and SO at high doses provide for its safety within the irregular and unstandardized doses used for human and animal treatment.

\section{Acknowledgement}

We are grateful for the tireless input into the laboratory work by Mr. Ndukui James especially during daily dosing of the rats. The invaluable laboratory support by Mr. Kisekka Magid and Dr. Afayoa Mathias is appreciated. Special thanks go to Swedish International Development Agency (Sida) for the financial support.

\section{Author contributions}

Denis Mugizi, John Kateregga, Deogracious Olila and Immaculate Nabukenya contributed to the study design, data collection and manuscript writing. Chris Rubaire-Akiiki, Deogracious Olila and Johan Höglund supervised the laboratory work and contributed to manuscript writing.

\section{References}

1. (2008) Ministry of Agriculture, Animal Industry \& Fisheries and Uganda Beareau of statistics, The National Livestock Census Report, Ministry of Agriculture. 
Citation: Nabukenya I, Rubaire-Akiiki C, Mugizi D, Kateregga J, Olila D, et al. (2014) Sub-acute Toxicity of Aqueous Extracts of Tephrosia vogelii, Vernonia amygdalina and Senna occidentalis in Rats. Nat Prod Chem Res 2: 143. doi:10.4172/2329-6836.1000143

2. Nalule AS, Mbaria JM, Olila D, Kimenju JW (2011) Ethnopharmacological practices in management of livestock helminthes by pastoral communities in the dry lands of Uganda. Livestock Research for Rural Development 23.

3. Nabukenya I, Rubaire-Akiiki C, Olila D, Ikwap K, Höglund J (2014) Ethnopharmacological practices by livestock farmers in Uganda: survey experiences from Mpigi and Gulu districts. J Ethnobiol Ethnomed 10: 9.

4. Tabuti JR, Kukunda CB, Waako PJ (2010) Medicinal plants used by traditional medicine practitioners in the treatment of tuberculosis and related ailments in Uganda. J Ethnopharmacol 127: 130-136.

5. Olila D, Bukenya-Ziraba R and Kamoga D (2007) Bio-prospective studies on medicinal plants used to manage poultry diseases in the Mount Elgon region of Uganda. J Pharmacol 1: 56-60.

6. Ssegawa P, Kasenene JM (2007) Medicinal plant diversity and uses in the Sango bay area, Southern Uganda. J Ethnopharmacol 113: 521-540.

7. Githiori JB, Höglund J, Waller PJ (2005) Ethnoveterinary plant preparations as livestock dewormers: practices, popular beliefs, pitfalls and prospects for the future. Anim Health Res Rev 6: 91-103.

8. Pieroni A, Howard P, Volpato G, Santoro RF (2004) Natural remedies and nutraceuticals used in ethnoveterinary practices in inland southern Italy. Vet Res Commun 28: 55-80.

9. Nanyingi MO, Mbaria JM, Lanyasunya AL, Wagate CG, Koros KB, et al. (2008) Ethnopharmacological survey of Samburu district, Kenya. J Ethnobiol Ethnomed 4: 14

10. The plant list.

11. Stevenson PC, Kite GC, Lewis GP, Forest F, Nyirenda SP, et al. (2012) Distinct chemotypes of Tephrosia vogelii and implications for their use in pest control and soil enrichment. Phytochemistry 78: 135-146.

12. Dzenda T, Ayo JO, Adelaiye AB, Adaudi AO (2007) Ethnomedical and veterinary uses of Tephrosia vogelii Hook F (Fabaceae): a review. Nigerian Veterinary Journal 28: 24-39.

13. Iwalokun BA, Efedede BU, Alabi-Sofunde JA, Oduala T, Magbagbeola OA, et al. (2006) Hepatoprotective and antioxidant activities of Vernonia amygdalina on acetaminophen-induced hepatic damage in mice. J Med Food 9: 524-530.

14. Alawa CB, Adamu AM, Gefu JO, Ajanusi OJ, Abdu PA, et al. (2003) In vitro screening of two Nigerian medicinal plants (Vernonia amygdalina and Annona senegalensis) for anthelmintic activity. Vet Parasitol 113: 73-81.

15. Yeap SK, Liang WS, Beh BK, Ho WY, Yousr AN, Alitheen NB (2013) In vivo antidiabetic and acute toxicity of spray-dried Vernonia amygdalina water extract. International Food Research Journal 20: 613-616.

16. Toyang NJ, Verpoorte R (2013) A review of the medicinal potentials of plants of the genus Vernonia (Asteraceae). J Ethnopharmacol 146: 681-723.

17. Adedapo AA, Otesile AT, Soetan KO (2007) Assessment of the Anthelmintic efficacy of the aqueous crude extract of Vernonia amygdalina. Pharmaceutical Biology 45: 564-568.

18. Yadav JP, Arya V, Yadav S, Panghal M, Kumar S, et al. (2010) Cassia occidentalis L.: a review on its ethnobotany, phytochemical and pharmacological profile. Fitoterapia 81: 223-230.

19. Tona L, Mesia K, Ngimbi NP, Chrimwami B, Okond'ahoka, et al. (2001) Invivo antimalarial activity of Cassia occidentalis, Morinda morindoides and Phyllanthus niruri. Ann Trop Med Parasitol 95: 47-57.

20. Verma L, Khatri A, Kaushik B, Patil UK, Pawar RS (2010) Antidiabetic activity of Cassia occidentalis (Linn) in normal and alloxan-induced diabetic rats. Indian J Pharmacol 42: 224-228.

21. Dzenda T, Ayo JO, Adelaiye AB, Adaudi AO and Ibrahim DG (2007) Preliminary investigation into the acute oral toxicity of Tephrosia vogelii leaves in mice. Niger Vet J 28: 47-52.

22. Ibrahim G, Abdurahman EM, Ibrahim H, Ibrahim NDG, Magaji MG (2011)
Toxicity and analgesic effects of Vernonia amygdalina del. (Asteraceae) leaf extract on mice. Int J Adv Pharm Biol Sci 1: 1-4.

23. Ojiako OA, Nwanjo HU (2006) Is Vernonia amygdalina hepatotoxic or hepatoprotective? Response from biochemical and toxicity studies in rats? Afr J Biotechnol 5: 1648-1651.

24. Panwar RS, Kumar N (2008) Cassia occidentalis toxicity causes recurren outbreaks of brain disease in children in Saharanpur. Indian J Med Res 127 413-414.

25. Vashishtha VM, John TJ, Kumar A (2009) Clinical \& pathological features of acute toxicity due to Cassia occidentalis in vertebrates. Indian J Med Res 130: $23-30$.

26. Suliman HB, Wasfi IA, Adam SE (1982) The toxicity of Cassia occidentalis to goats. Vet Hum Toxicol 24: 326-330.

27. Rogers RJ, Gibson J, Reichmann KG (1979) The toxicity of Cassia occidentalis for cattle. Aust Vet J 55: 408-412.

28. Silva MG, Aragão TP, Vasconcelos CF, Ferreira PA, Andrade BA, et al. (2011) Acute and subacute toxicity of Cassia occidentalis L. stem and leaf in Wistar rats. J Ethnopharmacol 136: 341-346.

29. Hartmann E, Strauss V, Eiben R, Freyberger A, Kaufmann W, et al. (2008) ESTP comments on the draft updated OECD test guideline 407. Exp Toxico Pathol 59: 297-300.

30. National Ressearch Council of the National Academes (2011) Guide for the Care and Use of Laboratory Animals, NIH publication. ( $8^{\text {th }}$ edn), 500 Fifth Street Washington D.C

31. Hussain T, Fareed S, Siddiqui HH, Vijaykumar M, Rao CV (2012) Acute and subacute oral toxicity evaluation of Tephrosia purpurea extract in rodents. Asian Pacific J Tropical Disease 2: 129-132.

32. Amole OO, Izegbu MC, Onakoya JAA, Dada MO (2006) Toxicity studies of the aqueous extract of Vernonia amygdalina. J Biomed Res 17: 39-40.

33. Test No. 425: Acute Oral Toxicity: Up-and-Down Procedure (2008) OECD Guidelines for the Testing of Chemicals.

34. Ouedraogo M, Baudoux T, Stévigny C, Nortier J, Colet JM, et al. (2012 Review of current and "omics" methods for assessing the toxicity (genotoxicity, teratogenicity and nephrotoxicity) of herbal medicines and mushrooms. J Ethnopharmacol 140: 492-512.

35. Sparg SG, Light ME, van Staden J (2004) Biological activities and distribution of plant saponins. J Ethnopharmacol 94: 219-243.

36. Nalule AS, Karue CN, Katunguka-Rwakishaya E (2011) Anthelmintic activity of Phytolacca dodecandra and Vernonia amygdalina leaf extracts in naturally infected small East African goats. Livestock Research for Rural Development 23.

37. Wasswa P, Olila D (2006) The in vitro Ascaricidal activity of selected indigenous medicinal plants used in ethno-veterinary practices in Uganda. Afr $\mathrm{J}$ Tradit Complement Alt Med 3: 94-103.

38. Matsumura F (1975) Toxicology of Insecticides. Plenum Press: New York.

39. Jafri MA, Jalis Subhani M, Javed K, Singh S (1999) Hepatoprotective activity of leaves of Cassia occidentalis against paracetamol and ethyl alcohol intoxication in rats. J Ethnopharmacol 66: 355-361.

40. Tasaka AC, Weg R, Calore EE, Sinhorini IL, Dagli ML, et al. (2000) Toxicity testing of Senna occidentalis seed in rabbits. Vet Res Commun 24: 573-582. 